\title{
Clarifying the Task of the Church in a Secular Age
}

\author{
Grace Mariette Agolia
}

\begin{abstract}
This paper argues that a proper theological understanding of the church-world relationship must avoid the tendency to dichotomize the two. Instead of regarding the world as a godless place, Christians must affirm in faith that the world is fundamentally graced, since it is the product of God's desire to communicate Godself. First, this paper draws upon the work of philosopher Charles Taylor to elucidate the meaning of "secularity" in the Western context. Then, the paper appeals to Karl Rahner's theology in exploring the prophetic and dialogical functions of the church with respect to society, which entails the church's own self-critical task as a listening, discerning, and synodal church. Rather than privatizing faith, the minority status of the church in society allows it to fulfill its mission more authentically as servant and sacrament of God's kingdom. Finally, this paper proposes that any impingement of the ostensible sacred-secular divide starts with the works of mercy because these directly confront the contingencies and vagaries of human life, touching upon our innate need for one another.
\end{abstract}

\section{Text}

\section{Introduction}

The church's task in a secular age is no different from its mission in any other time:

proclaiming the good news of salvation from God in Jesus Christ through the Holy Spirit. ${ }^{1}$ This mission is oriented both toward the world (ecclesia ad extra) and the ecclesial community itself

${ }^{1}$ In this paper, I use "church" to refer to the universal church and "Church" to designate the Catholic Church in particular, my own faith tradition. In quotations, I leave the original phrasing of the authors if they write "Church," for they speak from the faith tradition of Catholicism, though what they say is intended to apply to the whole Christian church. 


\section{AGOLIA: CLARIFYING THE TASK OF THE CHURCH}

(ecclesia ad intra). However, the approaches and parameters for pursuing this mission shift in every generation, as the church navigates changing historical circumstances. Professor Richard Lennan often reminds his students that the church must be the church in the $21^{\text {st }}$ century-or in any age - in a way that the church has never had to be before. This task requires both ongoing conversion to the heart of Christian faith and discernment of the Spirit, who animates the church's mission. My aim, then, is to clarify how living in a secular milieu informs the church's self-understanding and how it goes about proclaiming the kingdom of God. This modest exploration will proceed in three parts: 1) defining secularity and the challenge it presents to the church, 2) elucidating what it means for the church to exercise its prophetic function as a critic of society, and 3) describing how the church engages this task preeminently through the works of mercy.

\section{Defining Secularity and the Challenge It Presents to the}

\section{Church}

The guiding premise for these reflections is a proper understanding of the church-world relationship that avoids the tendency to dichotomize the two. ${ }^{2}$ Instead of regarding "the world",

\footnotetext{
${ }^{2}$ A more detailed consideration of this sacred-secular theme in relation to ecclesiology would investigate Israel's understanding of the sacred and the profane and its identity vis-à-vis the surrounding nations, how Jesus understood his mission to Israel, and how Paul's mission to the Gentiles spurred developments in ecclesial self-understanding. Further attention would need to be given to particular elements of the Christian doctrine of salvation as it pertains to ecclesiology and the presence of grace in the world, including how to interpret phrases such as "outside the Church there is no salvation" (extra Ecclesiam nulla salus) or the fullness of truth "subsists" (subsistit in) in the Catholic Church (Lumen gentium §8).

3 "The world" bears great multivalence in Christian discourse with both positive and negative connotations depending upon the context. The term could refer to the universe, planet Earth, human society, or even those elements of culture in opposition to the Christian message. Scripture, too, is somewhat ambiguous about "the

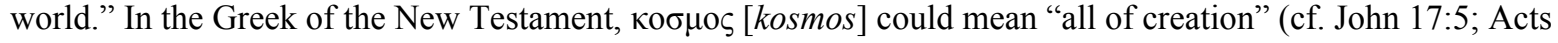
17:24; Rom 1:20; Eph 1:4), "humankind" (cf. Mark 14:9; Matt 13:38; John 1:10; 1 John 2:2), or the realm of sin (cf. Rom 12:2; 1 Cor 2:12; Jas 4:4; 1 John 2:15-17) — and these referents may overlap to varying degrees. I am grateful to Lumen et Vita editor Hayden Guy Cowart for encouraging me to name these distinctions explicitly. See also Michael J. Himes, "The Church and the World in Conversation: The City of God and 'Interurban' Dialogue,” New
} 


\section{AGOLIA: CLARIFYING THE TASK OF THE CHURCH}

as a godless place that the church has to infuse with grace, Christians must uphold in faith that the world is already fundamentally graced because it is the product of God's desire to communicate Godself. ${ }^{4}$ The world itself is sacramental of the God who gives, sustains, and redeems our life, and God has chosen to become a part of this world by taking on human nature in Jesus Christ.

Since the good news of salvation is transmitted in time, across space, and through culture, it is possible — indeed, necessary — for the church to discern the presence of the Holy Spirit amidst its historical circumstances. In doing so, the church both learns from the world- thus engaging in ongoing renewal so that it may communicate the Gospel more effectively—and critiques societal mores that obscure the truth of our humanity before God. ${ }^{5}$ Because grace has an "incarnational tendency," from the world. Rather, the church must immerse itself radically within the world as "leaven"” that rises toward the fullness of God's kingdom.

Therefore, given the graced reality of creation, the Incarnation's affirmation of all that is human apart from sin, and that the Spirit "blows where it wills" (i.e., it is not the sole possession

Theology Review 18 (2005), 28-29. For the purposes of this paper, the principal meaning behind my use of "the world" is "the world of human society," since this is the context most often referred to when speaking of the church's mission.

$4 \quad$ For more on Karl Rahner's insight into "quasi-formal causality," see, for example, "Nature and Grace" [orig. 1960], Theological Investigations, vol. 4, trans. K. Smyth (New York: Crossroad, 1982), 165-88.

${ }^{5} \mathrm{Cf}$. Second Vatican Council, "Pastoral Constitution on the Church in the Modern World," Gaudium et spes (Vatican.va: December 7, 1965), §44, §58.

${ }^{6}$ Karl Rahner, "Personal and Sacramental Piety,” Theological Investigations (vol. 2), trans. K.-H. Kruger (New York: Crossroad Publishing, 1990), 119.

${ }^{7}$ Gaudium et spes, $\$ 40$.

${ }^{8}$ In doing so, the church does not "dissolve" itself into the world, nor is it to be conflated with the kingdom, for each reality is distinct. For more discussion about the relations among church, world, and kingdom, please reference the aforementioned article by Michael Himes and also John Fuellenbach's essay, "The Church in the Context of the Kingdom of God,' in The Convergence of Theology: A Festschrift Honoring Gerald O'Collins, S.J., ed. Daniel Kendall, S.J. and Stephen T. Davis (Mahwah, NJ: Paulist Press, 2001), 221-37. 


\section{AGOLIA: CLARIFYING THE TASK OF THE CHURCH}

of the church), we cannot summarily write off secularity as totally inimical to the sacred. While secularity is not synonymous with "the world," Christians tend to conflate the two in common parlance. In such situations, those using the word "secular" tend to gesture vaguely, with genuine concern, toward the experience of widespread disregard for, and even hostility toward, God, authority, and definitive truth claims in Western society at large. ${ }^{9}$ This description is certainly not wrong, but it bears the risk of black-and-white generalization that may gradually devolve into a reactionary and bunker-like mentality: there is the world, with all its secular discontents, and here is the church, the guardian of truth, assailed by the tyranny of individualism and relativism.

While there are undoubtedly real ideological dangers, the situation is more nuanced than some might assume. Philosopher Charles Taylor suggests that secularization is more than simply the eradication of religion from the public sphere or the overall decline in religious consciousness. He describes it as the process by which the conditions of belief have changed from a time when belief in God was virtually unquestioned to a time in which belief in God is not only challenged but also understood as one alternative among others. It is thus difficult to maintain belief in this atmosphere of pluralism, coupled with widespread disenchantment and the shift from a transcendent frame of reference to an immanent one. ${ }^{10}$ This understanding of secularity allows us to broaden our sense of the myriad factors involved in the contemporary quest for authenticity and meaning.

\footnotetext{
${ }^{9}$ For the sake of brevity, I must curtail my considerations to the West. It is also the place of my own experience and observations. There is much more to be said, however, concerning the impact (or lack thereof) of secularity on the church in other societies around the world.

${ }^{10}$ Charles Taylor, A Secular Age (Cambridge, MA: The Belknap Press of Harvard University Press, 2007), $2-4$.
} 


\section{AGOLIA: CLARIFYING THE TASK OF THE CHURCH}

In my estimation, part of this change in the conditions of belief is that the very structures conveying and facilitating human experience of God have come into question. In a disenchanted and pluralistic society, the failures and sinfulness of the church throughout history present great stumbling blocks to faith. It is painful to see how the church professes to be a sign of God's love and yet so often forsakes this very vocation. As Prof. Lennan stated in a recent lecture exploring a theological response to the church's sexual abuse crisis, we must recognize that such a predicament for the church "is not simply an issue of governance, formation for ministry, or pastoral practice, as implicated as are all three in the need for a converted church. The sexual abuse crisis gnaws at faith; it casts a pall of suspicion over belief in the capacity of any human enterprise, let alone the church, to mediate grace."

With this in mind, the threat of the secular perceived by many Christians is, in some respects, less a crisis of theism than it is of the church's credibility, authority, and relevance. At least in the Western context, where we have steadily encountered the rise of "the nones" and those who identify as "spiritual but not religious," the credibility of a consciously religious orientation to life has become somewhat intertwined with the credibility of the Catholic Church in particular. Far from its place of influence in the politics of Christendom as a herald of divine authority, the church is for numerous people today the paragon of the pernicious effects of institutionalized religion - especially given the sexual abuse scandal in recent decades. Or, at best, the church is simply dismissed as woefully antiquated. In a time when the church can no longer assume the security of state-sponsored power and unquestioned respect for its authority, how may it reorient its approach to mission?

\footnotetext{
${ }^{11}$ Richard Lennan, "Seeking the Right Side of History: Theology and the Sexual Abuse Crisis," invited lecture at Villanova University (November 1, 2019), 8.
} 


\section{AGOLIA: CLARIFYING THE TASK OF THE CHURCH}

\section{The Church's Prophetic Function as a Critic of Society}

This reorientation is essentially a hearkening back to the church's nature as both pilgrim

and sign. ${ }^{12}$ The church is not an end in itself; in its liturgy and diakonia, the ecclesial community vigilantly proclaims and journeys toward the kingdom of God. Secularity, then, is perhaps not so detrimental to Christianity, but rather facilitates the church's prophetic task in the world.

According to Karl Rahner, secularization, "despite the danger of a sinful and atheistic interpretation inherent in it... is a process which, ultimately speaking, has been demanded and initiated by Christianity's own understanding of God, of the world, of man, of history, and of the nature of the Church herself." ${ }^{13}$ Rather than withdrawing from temporal affairs and privatizing faith, the church's minority status in society presents an opportunity for the church to fulfill its mission more authentically as servant and sacrament of God's reign. ${ }^{14}$

The church does this by highlighting the finite aspirations of humankind as a provisional reality and, thus, capable of alteration. ${ }^{15}$ The relative value of our goals does not mean that they are insignificant, however. What we do in this world and how we do it are quite serious in light of our eschatological destiny. The fundamentally graced reality of the world reveals the communal nature of salvation, implanting in us a movement toward God as our absolute future. ${ }^{16}$ The church, therefore, engages this task of "critical evaluation from the standpoint of a higher

\footnotetext{
${ }^{12}$ See Second Vatican Council, "Dogmatic Constitution on the Church," Lumen gentium (Vatican.va: November 21, 1964), §1 and $\S 48$ in particular.

${ }^{13}$ Karl Rahner, "The Function of the Church as a Critic of Society" [orig. 1971-72]. Theological Investigations (vol. 12) trans. D. Bourke (New York: Seabury, 1974), 236.

${ }^{14}$ Rahner, "The Function of the Church as a Critic of Society," 237-38.

${ }^{15}$ Rahner, "The Function of the Church as a Critic of Society," 235.

${ }^{16}$ Rahner, "The Function of the Church as a Critic of Society," 239.
} 


\section{AGOLIA: CLARIFYING THE TASK OF THE CHURCH}

goal," since grace provides us with this "perspective of infinitude." ${ }^{17}$ Thus, the church's task in a secular age has everything to do with proclaiming the transcendent value of human freedom, safeguarding human dignity, seeking justice for the poor and oppressed, and promoting solidarity and peace among all people. The church's social criticism is precisely the Gospel it preaches and tries to embody - the life-giving mercy of God incarnate in Jesus Christ.

In turn, this Gospel is the same measure by which the church must constantly pursue conversion to the Spirit animating its existence. ${ }^{18}$ Self-criticism is an intrinsic element of the church's nature, based on the tension between what the church seeks to be and what the church in fact is as pilgrim. ${ }^{19}$ In a secular age, the church's own self-criticism is especially important for fulfilling its prophetic function as a critic of society credibly. In doing so, the church must place a high priority on listening and dialogue, and always with a preferential option for those who are poor, marginalized, or excluded in society. It is to these "least ones" whom Jesus addresses his mission in particular: "The Spirit of the Lord is upon me, because he has anointed me to bring glad tidings to the poor. He has sent me to proclaim liberty to captives and recovery of sight to the blind, to let the oppressed go free, and to proclaim a year acceptable to the Lord" (Luke 4:18-19; cf. Isa 61:1-2).

\section{The Works of Mercy as the Church's Critical Task}

The church thus engages its critical task primarily through demonstrating love of neighbor, through which it undertakes its own ongoing summons to conversion. In secular society, the church's witness to love of neighbor is especially crucial—for the church's own

\footnotetext{
${ }^{17}$ Rahner, "The Function of the Church as a Critic of Society," 240.

${ }^{18}$ Rahner, "The Function of the Church as a Critic of Society," 235.

${ }^{19}$ Rahner, "The Function of the Church as a Critic of Society," 230.
} 


\section{AGOLIA: CLARIFYING THE TASK OF THE CHURCH}

credibility and for the sake of justice — and this hospitality should be demonstrated not in a broadly humanitarian sense, but as uniquely expressed in the life of Jesus. ${ }^{20}$ For Jesus, who was steeped in the Hebrew Scriptures, God's mercy (hesed) is not an abstract idea. It is a concrete reality through which divine love reveals itself to the world; it is the very mode of the narrative of salvation. ${ }^{21}$ This history of salvation, moreover, culminates in Jesus's very person as the only-begotten Son of God, the incarnate Word of God's mercy to the world. He exemplifies the personal encounter with God's mercy and exhorts his disciples to do the same: "Be merciful as your heavenly Father is merciful" (Luke 6:36; cf. Matt 5:48).

Therefore, the church's distinctively prophetic function as a critic of society consists in these concrete actions: feeding the hungry, giving drink to the thirsty, welcoming the stranger, clothing the naked, caring for the sick, and visiting the imprisoned (Matt 25:31-46). To act thus is to embody the liberating compassion of the God of Israel as particularized in the person of Jesus Christ, "the face of the Father's mercy." 22 Pope Francis himself repeatedly affirms that this mercy "is the very foundation of the Church's life" and that "[ $\mathrm{t}]$ he Church's very credibility is seen in how she shows merciful and compassionate love.",23 The church's commission is "to announce the mercy of God, the beating heart of the Gospel." ${ }^{24}$ Ecclesial life is "authentic and credible only when [the church] becomes a convincing herald of mercy." Again, he states that the church's "primary task... is to introduce everyone to the great mystery of God's mercy by

\footnotetext{
${ }^{20}$ Karl Rahner, "The Foundation of Belief Today” [orig. 1975], Theological Investigations (vol. 16), trans. D. Moreland (New York: Seabury, 1979), 20-21.

${ }^{21}$ Francis, "The Face of Mercy," Misericordiae Vultus, Bull of Indiction of the Extraordinary Jubilee of Mercy (Vatican.va: April 11, 2015), §6. Francis cites these verses as examples: Pss 103:3-4; 146:7-9; and 147:3, 6.

${ }^{22}$ Francis, Misericordiae Vultus, $§ 1$.

${ }^{23}$ Francis, Misericordiae Vultus, $\$ 10$.

${ }^{24}$ Francis, Misericordiae Vultus, $\$ 12$.
} 


\section{AGOLIA: CLARIFYING THE TASK OF THE CHURCH}

contemplating the face of Christ. The Church is called above all to be a credible witness to mercy, professing it and living it as the core of the revelation of Jesus Christ." ${ }^{25}$

Any impingement of the ostensible sacred-secular divide, then, must start with the works of mercy, because these directly confront the contingencies and vagaries of human life, touching upon our innate need for one another. The experience of human solidarity therein is the beginning of a religious orientation, whether or not one explicitly names it "Christian." ${ }^{26}$ For Thomas Aquinas, the virtues of religion and mercy go together: while one renders due reverence to God in worship, if one is not prepared to act with mercy towards others, then this reverence due God is incomplete. ${ }^{27}$ The works of mercy properly direct us toward and form us in that caritas which binds us directly to God. Similarly, Rahner speaks of the unity of the love of God and neighbor, grounding this assertion in the Incarnation, namely, that God has chosen to become our neighbor: "When we read in Scripture that he who loves his neighbour has fulfilled the law, this is the ultimate truth, because God himself has become this neighbour. He who is at once the nearest to us and the farthest from us is always the one person who is accepted and loved in our nearest and dearest." ${ }^{28}$ In demonstrating the works of mercy, the church engages in liturgical formation, subtly reminding society that human beings have, by grace, a religious orientation. $^{29}$ In love of neighbor, we are summoned to love of God.

${ }^{25}$ Francis, Misericordiae Vultus, $\$ 25$.

${ }^{26}$ A phenomenological consideration of "touch" in the works of mercy as fostering this human solidarity would contribute to this argument.

${ }^{27}$ Thomas Aquinas, Summa Theologiae II.II.30.4; II.II.81.1.

${ }^{28}$ Karl Rahner, “On the Theology of the Incarnation” [orig. 1958], Theological Investigations, vol. 4, trans. K. Smyth (New York: Crossroad, 1982), 119. See also "Reflections on the Unity of the Love of Neighbour and Love of God" [orig. 1965], Theological Investigations, vol. 6, trans. K.-H. \& B. Kruger (New York: Crossroad, 1974), 231-49. Cf. Mark 12:28-34; Matthew 22:34-40.

${ }^{29}$ Another insight for future exploration would be how the church engages in liturgical formation in a secular milieu, with particular attention to the role of embodiment, since Taylor's work speaks of "excarnation" as a 


\section{AGOLIA: CLARIFYING THE TASK OF THE CHURCH}

What might this hospitality look like concretely today? An apt example of the church discerning and responding to the Spirit is a recurring event called "Ripples of Kindness" (RoK), an interfaith-led community meal in downtown Toronto at the northeastern corner of Sherbourne and Carlton. ${ }^{30}$ The event enables people from different cultures, faith traditions, and walks of life, particularly those affected by poverty, homelessness, marginalization, mental health, addiction, or stigmatization, to gather for a free lunch in a spirit of friendship. Nearly every Saturday afternoon at Sacré-Coeur Church, volunteers arrive to assemble tables and chairs, prepare the meal, lead prayer, serve food, and clean up afterwards. During the community meal, people listen to each other's stories, play chess, do crafts, and listen to music. The inspiration for this event began with a confirmation class handing out flyers inviting people on the streets to a meal and conversation, later growing into a discussion among various faith communities in the area about how they could practice hospitality together in a way that would help transform society, from the Christian love of God and neighbor to the Sikh practice of seva ("selfless service").

I am convinced that the intentional act of sharing meals with one another, especially with those who are downtrodden, is a deeply impactful way that the church can exercise its prophetic function in speaking of grace and sacramentality to a secular age. ${ }^{31}$ This simple habitus of hospitality and conversation invites people to participate in a culture of encounter, an impetus that cannot be imposed from above but that must begin with you and me in our daily lives. John

symptom of living in a secular age. James K. A. Smith's work on cultural liturgies is also helpful, though he tends to dichotomize the church and the world.

${ }^{30}$ For more information, see this article, "Church on the Street: In this 'pop-up' community, all are one" by Daniel Kinghorn, a deacon of the Archdiocese of Toronto (The Catholic Register, November 12, 2018): https:/www.catholicregister.org/opinion/columnists/item/28415-church-on-the-street-in-this-pop-up-community-allare-one.

${ }^{31}$ This, in turn, begs the ecumenical question of how we might think about participation in the Eucharist. 


\section{AGOLIA: CLARIFYING THE TASK OF THE CHURCH}

Fuellenbach speaks of two "feast" aspects in the church's missionary task. The first is in proclaiming the presence of God's kingdom in word and sacrament, "feasting" on it "most intensely in the Eucharistic meal celebration." The second is in promoting “"feasts' where people of all races and cultures sit together and enjoy each other's company in life-giving relationships and genuine compassion. It is precisely here that God's kingdom makes itself felt and can be experienced as present in the midst of human affairs." ${ }^{32}$ RoK seems to be a model of this second "feast" aspect of the church's missionary task in a secular age.

Additionally, Rahner speaks of the importance of grassroots communities of believers for the effectiveness of the Christian message today. He writes, "The Church, in its present minority situation, where it is no longer supported by the secular powers of society, can only be the Church — and can only continually become the Church—by deliberately being the Church from below." ${ }^{33}$ Hospitality movements such as the Catholic Worker, L'Arche, Romero House, Heart's Home, and the Community of Sant'Egidio remind the church how to engage the world as a critic of society. These movements are dedicated to the poor and marginalized; grounded in prayer, companionship, and social action; and have grown to be ecumenical and interfaith in their outreach, while honoring the spirit of the founding tradition. They teach the church that its prophetic function is not to judge who is "outside" but to model hospitality to all, especially to

\footnotetext{
${ }^{32}$ Fuellenbach, "The Church in the Context of the Kingdom of God," 236.

${ }^{33}$ Karl Rahner, "Transformations in the Church and Secular Society" [orig. 1975], Theological Investigations (vol. 17), trans. M. Kohl (New York: Crossroad, 1981), 178-9.
} 


\section{AGOLIA: CLARIFYING THE TASK OF THE CHURCH}

strangers in its midst, ${ }^{34}$ and that such merciful action requires creativity, gumption, determination, courage, and most of all, hope.

\section{Conclusion}

When we affirm that the world is fundamentally graced, realizing that the boundary between sacred and secular is much more permeable than commonly thought, this does not mean we dilute the Christian message, relativize truth, or conflate Christian living with the latest trend. There are serious shadowlands in our world, and the church must exercise its prophetic function in proclaiming the dawn of God's justice and mercy. The primary way it must do this is by promoting and embodying genuine love of neighbor. As much as the church would prefer to distance itself from the messiness of our world, we must realize that the world's problems are also the church's problems because we share the same history of human freedom. What we avow is this: "The joys and the hopes, the griefs and the anxieties of the [people] of this age, especially those who are poor or in any way afflicted, these are the joys and hopes, the griefs and anxieties of the followers of Christ." the world, for the salvation the church proclaims is a message intended for every person. When the church engages in the work of criticism and conversion, listening and discernment, proclamation and hospitality, we can credibly convince others that the Gospel is not "fake news," but rather, good news indeed.

\footnotetext{
${ }^{34}$ In Hebrews 13:1-2, the author concludes the sermon with an exhortation to believers to love one another and to love strangers: "Let brotherly love ( $\varphi 1 \lambda \alpha \delta \varepsilon \lambda \varphi^{\prime} \alpha$, philadelphia) continue. Do not neglect hospitality ['strangerly love'] ( $\varphi \imath \lambda \mathrm{o} \xi \varepsilon v i ́ \alpha \varsigma$, philoxenias)..." Once again, I am grateful to Hayden Guy Cowart for this reference. In addition, Mary Jo Leddy's The Other Face of God: When the Stranger Calls Us Home (Maryknoll, NY: Orbis Books, 2011) is a deeply thought-provoking resource that suggests just how the church might learn from hospitality movements like her own (Romero House) in order to proclaim the Gospel more effectively in a secular milieu.

${ }^{35}$ Gaudium et spes $§ 1$.
} 


\section{AGOLIA: CLARIFYING THE TASK OF THE CHURCH}

\section{Bibliography}

Aquinas, Thomas. Summa Theologiae. Second revised edition, translated by the Fathers of the English Dominican Province (1920; New Advent, 2008).

http://www.newadvent.org/summa/index.html.

Francis. "The Face of Mercy." Misericordiae Vultus (April 11, 2015). Bull of Indiction of the Extraordinary Jubilee of Mercy. Vatican.va.

Fuellenbach, John. "The Church in the Context of the Kingdom of God." In The Convergence of Theology: A Festschrift Honoring Gerald O'Collins, S.J. Edited by Daniel Kendall, S.J. and Stephen T. Davis. Mahwah, NJ: Paulist Press, 2001. 221-37.

Himes, Michael J. "The Church and the World in Conversation: The City of God and 'Interurban' Dialogue.' New Theology Review vol. 18 (February 2005): 27-35.

Leddy, Mary Jo. The Other Face of God: When the Stranger Calls Us Home. Maryknoll, NY: Orbis Books, 2011.

Lennan, Richard. "Seeking the Right Side of History: Theology and the Sexual Abuse Crisis." Invited lecture at Villanova University. November 1, 2019.

Rahner, Karl. "The Foundation of Belief Today" [orig. 1975]. Theological Investigations, vol. 16. Translated by D. Moreland. New York: Seabury, 1979. 3-23.

. "The Function of the Church as a Critic of Society" [orig. 1971-72]. Theological Investigations, vol. 12. Translated by D. Bourke. New York: Seabury, 1974. 229-49.

. "Personal and Sacramental Piety." Theological Investigations, vol. 2. Translated by K.-H. Kruger. New York: Crossroad, 1990. 109-33.

- "Reflections on the Unity of the Love of Neighbour and Love of God" [orig. 1965]. Theological Investigations, vol. 6. Translated by K.-H. \& B. Kruger. New York:

Crossroad, 1974. 231-49.

. "On the Theology of the Incarnation" [orig. 1958]. Theological Investigations, vol. 4. Translated by K. Smyth. New York: Crossroad, 1982. 105-20.

—. "Transformations in the Church and Secular Society" [orig. 1975]. Theological Investigations, vol. 17. Translated by M. Kohl. New York: Crossroad, 1981. 167-80.

Second Vatican Council. "Pastoral Constitution on the Church in the Modern World." Gaudium et spes (December 7, 1965). Vatican.va. 


\section{AGOLIA: CLARIFYING THE TASK OF THE CHURCH}

— . "Dogmatic Constitution on the Church." Lumen gentium (November 21, 1964). Vatican.va.

Taylor, Charles. A Secular Age. Cambridge, MA: The Belknap Press of Harvard University Press, 2007. 